\title{
CONSUMO DE MATERIAL BIOLÓGICO, VULNERABILIDADE E BIOBANCOS
}

\author{
Roberto Henrique Pôrto Nogueira ${ }^{1}$ \\ Alexandra Clara Ferreira Faria ${ }^{2}$
}

\section{RESUMO}

Objetiva-se investigar se há relação de consumo na disposição de material biológico humano para instituição de biobancos. A relevância da empreitada é evidente porque o problema estudado envolve a regularidade do avanço de terapias e de pesquisas clínicas. A pesquisa é jurídico-teórica, sobretudo bibliográfica. Como resultado, conclui-se que o negócio jurídico existencial se formata como doação neutra e que o doador, apesar da gratuidade e da inexistência de consumo direto de serviços de saúde que se valem dos biobancos mantidos, pode ser equiparado a consumidor, na medida em que seja reconhecida remuneração, ainda que indireta, dos mantenedores dessas bases.

Palavras-chave: Biobancos; Vulnerabilidade; Consumidor; Doação; Biotecnologia.

\section{CONSUMPTION OF BIOLOGICAL MATERIAL, VULNERABILITY AND BIOBANKS}

\begin{abstract}
This study aims to investigate whether there is a relation of consumption in the disposal of human biological material for biobanks. The relevance of the work is evident once the problem involves the regularity of the advancement of therapies and clinical research. The research is theoretical, mainly bibliographical. It is concluded that the existential legal business is formed as a neutral donation and that the donor, despite the gratuity and lack of direct consumption of health services that rely on biobanks, can be assimilated to consumers, since there is at least indirect remuneration of the maintainers of these bases.
\end{abstract}

Keywords: Biobanks; Vulnerability; Consumer; Donation; Biotechnology.

\section{CONSIDERAÇÕES INICIAIS}

Biobancos são bancos de armazenamento de amostras biológicas humanas. A instituição de biobancos tem sido alternativa para a viabilização do desenvolvimento da biotecnologia, que incrementa o estado da técnica pela via da utilização de organismos vivos e seus derivados. Usualmente, esse material biológico destina-se a pesquisas clínicas, científicas e tecnológicas, de natureza interdisciplinar. Contudo, é comum a articulação de

\footnotetext{
${ }^{1}$ Doutor e Mestre em Direito Privado pela PUCMinas. Especialista em Direito Tributário pela Faculdade de Direito Milton Campos. Professor Adjunto do Curso de Graduação e Mestrado Acadêmico em Direito da UFOP. ${ }^{2}$ Doutora em Direito Privado pela PUCMinas. Mestre em Direito Constitucional pela UNAERP - Ribeirão Preto/SP. Especialista em Direito Público da UNIFEMM. Professora Adjunto IV da Faculdade Mineira de Direito da PUCMinas. Professora da Pós Graduação do Instituto de Ensino Continuado -IEC da PUCMinas. Advogada.
} 
biobancos com finalidades independentes de investigações científicas, como, por exemplo, para realização de terapias de reprodução humana assistida, aconselhamento genético, decodificação do DNA, pesquisas com células-tronco. Logo, essas descobertas fazem emergir celeumas intrínsecas ao trato negocial dos envolvidos recorrentemente vulneráveis, que são determinantes do processamento jurídico.

Quando instituídos com o fito de subsidiar pesquisa clínica, os biobancos encontram algum regramento por parte do Conselho Nacional de Saúde (CNS) e Conselho Federal de Medicina (CFM). Merece destaque, ainda, a Lei de Biossegurança e seus decretos regulamentadores.

Para que as atividades dessas bases de dados e de materiais biológicos humanos possam ser desenvolvidas, é necessário que os titulares dessas amostras estejam dispostos a colaborar, gratuitamente. Trata-se do comando constitucional do art. 199, $\S 4^{\circ}$, segundo o qual cabe à lei dispor sobre condições e requisitos que facilitem a remoção de órgãos, tecidos e substâncias humanas para fins de transplante, pesquisa e tratamento, bem como a coleta, processamento e transfusão de sangue e seus derivados, sendo vedado todo tipo de comercialização (BRASIL, 1988).

Desta forma, os colaboradores tornam-se doadores de material biológico e também, eventualmente, conforme o caso, sujeitos de pesquisa, mediante adesão ao protocolo investigativo, bem como com a anuência na coleta e armazenamento de frações ou amostras de seu próprio corpo. Essa adesão é realizada por meio de negócio jurídico bilateral, de cunho existencial, mas que versa sobre espécimes genéticas ou biológicas autônomas ao corpo.

Desse modo, cabe indagar se, a despeito da gratuidade desse negócio jurídico existencial, cabe falar em configuração de relação de consumo e, por conseguinte, da aplicabilidade do Código de Defesa do Consumidor (BRASIL, 1990), para possibilitar a incidência em concreto do regime jurídico favorável ao doador vulnerável.

A relevância da empreitada é evidente na medida em que o avanço em terapias e em pesquisas clínicas envolvendo biobancos depende, para a sua regularidade, do regime jurídico aplicável, sobretudo para aferir em quais circunstâncias o titular da amostra biológica humana doada pode invocar, além da normativa já mencionada e do arcabouço próprio dos direitos da personalidade, o sistema protetivo próprio do sujeito vulnerável na relação de consumo.

A hipótese é a de que, a despeito da gratuidade do negócio jurídico existencial da doação de material biológico para armazenamento em biobancos, tratando-se de situação na qual se verifique remuneração, ainda que indireta, de serviços relacionados (como nos casos Revista de Biodireito e Direito dos Animais | e-ISSN: 2525-9695 | Salvador | v. 4 | n. 1 | p. 64 - 83 | Jan/Jun. 
de biobancos mantidos para o custeio de terapias médicas ou patrocinados para investigação e elaboração de drogas), conforma-se típica relação de consumo, apta a reclamar a incidência do regime consumerista.

Para tanto, a metodologia utilizada é a jurídico-teórica, com coleta de dados em material documental, obtidos por meio de pesquisa bibliográfica, visando a uma contribuição de conteúdo específico e técnico.

\section{O CONSENTIMENTO PARA A DISPOSIÇÃO DE MATERIAL BIOLÓGICO PARA BIOBANCOS BRASILEIROS}

O corpo contemporâneo é entendido como uma unidade funcional. Assim, tem-se não só como um corpo físico, mas, também, um corpo eletrônico, um corpo virtual, um corpo político, um corpo biológico, inclusive, “[...] em lugares fisicamente distintos, que devem ser protegidos por garantir o exercício da autonomia privada de cada pessoa [...]" (RODOTÀ, 2010, p. 100, tradução nossa). ${ }^{3}$ A proteção do corpo não pode ser aferida de modo marginal aos direitos da personalidade e à noção de dignidade.

Diante disso, a concepção de dignidade no contexto do Estado Democrático de Direito concretiza-se com o exercício da autonomia privada de cada pessoa humana. Por conseguinte, consiste no livre desenvolvimento de sua pessoalidade, ou seja, na sua autodeterminação.

Daí emergem os desafios para a definição do regime jurídico das relações que gravitam em torno da instituição de biobancos. Trata-se de questão de enfrentamento necessário, haja vista a utilidade inconteste dessas bases de dados e materiais para o desenvolvimento do estado da técnica da ciência.

[...] as inovações tecnológicas, incorporadas ao cotidiano, têm provado sua contribuição para o prolongamento da vida, o combate a doenças, o alívio da dor e dos sofrimentos e a melhoria da qualidade de vida. Porém, a natureza intrínseca dessas inovações cria falsas expectativas e demandas mal controladas. (MOTA, 1997, p. 115).

Aos doadores de materiais biológicos humanos para biobancos criados para pesquisas clínicas são conferidas prerrogativas, muitas delas ligadas ao consentimento e à

3 [...] en lugares fisicamente distintos, que debe ser protegida para hacer a posible el derecho de toda persona a la autodeterminación.

Revista de Biodireito e Direito dos Animais | e-ISSN: 2525-9695 | Salvador | v. 4 | n. 1 | p. 64 - 83 | Jan/Jun. 
responsabilidade do pesquisador.

O consentimento é a exteriorização da autonomia privada. Nesses casos de biobancos para pesquisas clínicas, reflete uma relação contratual, sem conteúdo econômico, para participação nessas investigações científicas. No aspecto jurídico, trata-se de um negócio jurídico, pois o sujeito da pesquisa deve possuir a capacidade de autodeterminação. Seus requisitos de validade traçam o contorno para sua tipificação, e a vontade, como manifestação da necessidade de autodeterminação, exige uma conduta pautada na boa-fé das partes para a realização de pesquisa clínica.

Assim,

[...] a boa-fé é chamada a depor em dois níveis: no campo da determinação das prestações secundárias e da delimitação da própria prestação principal, ela age sobre as fontes, como instrumento de interpretação e de integração; no dos deveres acessórios, ela tem um papel dominante na sua gênese. (CORDEIRO, 2007, p. 602).

Tendo em vista que o material biológico humano se desdobra do corpo cuja integridade é direito assegurado em algumas categorias privilegiadas (direito da personalidade, direito fundamental, direito humano), o termo de consentimento para a sua coleta, armazenamento e destinação é de suma importância. Trata-se de um instrumento de proteção de pessoa vulnerável, qual seja, o titular do material. Por meio do instrumento de formalização do consentimento, não só o "cidadão encontra-se protegido contra os abusos do Estado, por meio do exercício dos seus direitos fundamentais, mas, igualmente, ele está protegido contra atos ilícitos que venham a ser perpetrados contra seus direitos de personalidade" (GOZZO; LIGIERA, 2012, p. 94).

O termo de consentimento deve preservar autonomia e a boa-fé dos sujeitos vulneráveis com interesses envolvidos na instituição de biobancos. Logo, deve contemplar informação ampla acerca de riscos previsíveis, tanto no âmbito da saúde quanto no âmbito social.

Portanto, verifica-se que, para a instituição de biobancos, sobretudo para a realização da pesquisa clínica, mister se faz a responsabilidade do pesquisador, através da informação consciente do objeto e dos efeitos ao titular da amostra biológica humana, para que, assim, possa ter validade seu consentimento.

Ocorre que o consentimento, na pesquisa clínica, por envolver seres humanos, exige uma regulação rigorosa, pois o direito à saúde e integridade física são direitos da personalidade. Como dito, os direitos da personalidade têm por objeto bens e valores Revista de Biodireito e Direito dos Animais | e-ISSN: 2525-9695 | Salvador | v. 4 | n. 1 | p. 64 - 83 | Jan/Jun. 
essenciais da pessoa humana, em seu aspecto físico, intelectual e moral, sob a proteção constitucional do Estado.

A inobservância ou violação de quaisquer cláusulas do termo de consentimento e mesmo da cláusula geral de tutela dos direitos da personalidade importa a responsabilidade do mantenedor do biobanco.

Havendo interesses violados no contexto da relação jurídica formada entre doador de material biológico humano e mantenedor dos biobancos, há de se cogitar da eventual configuração de relação de consumo e da incidência, para além da normativa própria de regência e dos direitos da personalidade, do Código de Defesa do Consumidor (BRASIL, 1988).

\section{BIOBANCOS NO BRASIL E PRERROGATIVAS DOS TITULARES DAS AMOSTRAS}

Diante dos avanços das pesquisas clínicas, dos avanços da engenharia genética, de desenvolvimento de novos fármacos, houve uma necessidade de armazenamento de informações genéticas e clínicas, cujo objeto de pesquisa consiste em amostras de material biológico humano, que, por sua vez, será armazenado em biobancos.

E se os biobancos evidenciam-se, num primeiro momento, no campo das pesquisas clínicas, é exatamente nesse panorama que sua primeira regulamentação acontece.

Os biobancos são "uma coleção organizada de material biológico humano e suas informações associadas, armazenados para fins de pesquisa, conforme recomendações e/ou normas técnicas, éticas e operacionais predefinidas" (ASHTON-PROLLA et al., 2009, p. 74). Além disso, destina-se, também, ao armazenamento de informações associadas ao sujeito da pesquisa, guardada a confidencialidade. $O$ intuito consiste na confidencialidade e no gerenciamento dessas informações e do material biológico humano.

Entretanto, os biobancos possuem atividades diferentes, com características específicas, podendo ter várias destinações, em virtude de ser uma palavra polissêmica, podendo ter vários significados, pois

[...] Tradicionalmente, seu significado liga-se à coleção de material biológico, seja humano ou de animal, para estudo e pesquisa e informações associadas. Alude-se a biobancos populacionais; biobancos de doenças específicas, como o câncer; biobancos genéticos; biobancos de DNA, estes também podendo ter finalidade forense; biobancos assistenciais, como os de sangue e córneas; biobancos de células e tecidos, [...] (MARTINS-COSTA; FERNANDES, 2012, p. 226). 
Diante disso, verifica-se que, nas atividades dos biobancos, encontra-se presente o interesse público, que é revelado não só na pesquisa clínica, mas, também, no desenvolvimento do direito à saúde e na proteção dos direitos da personalidade. Diante disso, compete-lhe a formulação de políticas públicas de regulação dessas atividades.

Os biobancos devem desenvolver uma sistematização de suas informações e armazenamento de amostra biológica humana. Trata-se de aspectos específicos de sua atividade, delimitando o objeto e o consentimento do doador do material, além dos aspectos éticos referentes à proteção dos direitos da personalidade, preservando a privacidade dos participantes e definindo os seus contornos.

A definição dos biobancos dependerá de sua destinação, isto é, da atividade desenvolvida, como:

[...] o estabelecimento de redes de pesquisa; compartilhamento da espécime armazenada e/ou das informações a ela associadas; a otimização dos recursos humanos e econômicos de pesquisa; o cuidado e o estudo harmonizado para a busca de padrões técnicos e ambientais relacionados ao material biológico armazenado; o estímulo à transferência de tecnologia entre os grupos de pesquisa; a organização e a informatização dos ambientes armazenadores de material biológico e das respectivas informações associadas e o estabelecimento de marcos regulatórios e diretrizes éticas para o seu funcionamento, dentre outras atividades. (MARTINS-COSTA; FERNANDES, 2012, p. p. 227-228).

Os biobancos podem ser públicos ou privados. Podem, também, ser mantidos por hospitais, centros de pesquisas, universidades, dentre outros. Diante disso, haverá uma variação de sua classificação em razão da destinação. Podem ser banco de sangue, banco de sêmens, banco de córneas, banco de tecidos, bem como o banco para pesquisa clínica.

A definição do regime jurídico dos biobancos é fundamental para o desenvolvimento científico. São imprescindíveis no panorama atual, tendo em vista a quantidade considerável de amostras biológicas humanas, a sistematização das informações associadas, os objetos de pesquisa clínica. Assim, servem de instrumentos para alavancar as pesquisas clínicas e as terapias relacionadas, estimular a modificação das políticas de saúde pública. A importância crescente do estudo e o diagnóstico de doenças contribuíram, assim, para uma evolução na melhoria de tratamentos, e consagrando, dessa maneira, a concepção de saúde como direito.

Nesse sentido, conforme lição de Carlos Maria Romeo Casabona e Jurgen W. Simon, os "[...] biobancos são um passo intermediário em um processo que produz uma coleção de dados e materiais que facilitam ainda mais a pesquisa" (ROMEO CASABONA; SIMON, 
2011, p. 06, tradução nossa). ${ }^{4}$

Os biobancos, portanto, além de compreenderem a chave para o desenvolvimento da pesquisa clínica, proporcionam diagnósticos genéticos, tratamentos específicos de doenças genéticas, o desenvolvimento de fármacos para tratamento. Em tudo, possui o potencial de contribuir para a concepção da saúde como direito, tendo em vista também o caráter preventivo, possibilitando a cada pessoa a real identificação do seu corpo.

Os biobancos necessitam de instalações físicas de armazenamento criogênico das amostras biológicas humanas. Dependem de tecnologias para produção de temperaturas muito baixas, através do uso do nitrogênio líquido ou dióxido de carbono sólido. Proporcionam o resfriamento dessas amostras a temperaturas muito baixas, por exemplo, $-120^{\circ} \mathrm{C}$, visando, assim, à preservação do material, evitando sua deterioração ao longo do tempo. Mesmo que o material biológico humano seja oriundo de um negócio jurídico gratuito, cabe exigir, tanto de quem o mantém quanto de quem ele se beneficia, um sistema tecnológico de registro da amostra biológica humana, de identificação e preservação de dados, de eventual anonimato [confidencialidade], de localização física, de episódios de manipulação e descongelamento, de entrada e de saída do armazenamento criogênico. (BAKER, 2012). A depender da complexidade dos materiais e dos dados, é possível que interessados, envolvidos em negócios jurídicos gratuitos (caso dos doadores de material) ou onerosos (financiamento de pesquisas com drogas, pacientes beneficiários diretos dos biobancos e prestadores de serviços correlatos), tenham a exigência de investimento econômico para desenvolvimento de software de gerenciamento da base de dados. O biobanco "[...] não é só uma coleção organizada de material biológico, mas também um complexo banco de dados com base em software desenvolvido pela empresa" (DUCATO; PERRA, ZUDDAS, 2014, p. 93, tradução nossa). ${ }^{5}$

Os biobancos para pesquisa clínica, em razão do uso de amostra biológica humana, adotam o princípio da gratuidade “[...] em todo o processo de doação, armazenamento, transferência e utilização de amostras, tanto os doadores como para os depositários, e estabelece a necessidade de definir padrões de qualidade e segurança em tratamento e gestão das mesmas" (ARRIBAS; DÍAZ, 2011, p. 208, tradução nossa). ${ }^{6}$

\footnotetext{
${ }^{4}[\ldots .$.$] biobanks are an intermediate step in a process that produces a collection of data and materials that facilitate$ further research. Tradução nossa).

5 [...] the biobank held by the company is not only an organized collection of biological material, but also a complex database based on software developed by the company.

6 [...] em todo el processo de donación, almacenamiento, cesión y utilización de muestras, tanto para los sujeitos fuente como para los depositários, y estabelece la necessidade de fijar estándares de calidad y seguridade em el tratamento y gestión de lãs mismas.
}

Revista de Biodireito e Direito dos Animais | e-ISSN: 2525-9695 | Salvador | v. 4 | n. 1 | p. 64 - 83 | Jan/Jun. 
O intuito da gratuidade nos biobancos para pesquisa clínica replica-se para os demais. Afinal, trata-se do comando constitucional do art. $199, \S 4^{\circ}$, segundo o qual cabe à lei dispor sobre condições e requisitos que facilitem a remoção de órgãos, tecidos e substâncias humanas para fins de transplante, pesquisa e tratamento, bem como a coleta, processamento e transfusão de sangue e seus derivados, sendo vedado todo tipo de comercialização (BRASIL, 1988).

No Brasil, o estudo acerca dos bancos de amostra genética para pesquisas encontrase muito incipiente. Entretanto, embora tenha presente um campo de justificação da norma, esta ainda não se efetivou, existindo somente resolução e portaria ministerial dispondo sobre o tema:

No Brasil, as pesquisas envolvendo regulamentos de seres humanos são protegidas pelas resoluções do Conselho Nacional de Saúde, que, apesar de não ter o poder normativo das disposições legais, configura diretrizes éticas e regulamentares que dizem respeito aos pesquisadores de certas prescrições, como é o caso da aprovação pelo Comitê de Ética de determinada pesquisa. (SÁ, 2011, p. 33, tradução nossa). ${ }^{7}$

Os biobancos brasileiros são regulados pela Resolução do Conselho Nacional de Saúde $\mathrm{n}^{\circ}$ 441, de 12 de maio de 2011 e pela Portaria Ministerial do Ministério da Saúde $\mathrm{n}^{\circ}$ 2.201, de 14 de setembro de 2011.

Os biobancos no Brasil são definidos como uma coleção organizada de material biológico humano e informações associadas, coletados e armazenados, sobretudo, para fins de pesquisa. Assim, há um regulamento ou normas técnicas, éticas e operacionais predefinidas, sob responsabilidade e gerenciamento institucional, sem fins comerciais, nos termos da resolução e portaria ministerial.

A regulação brasileira demonstra a necessidade do consentimento prévio do titular da amostra biológica humana. Nessa regulação há o conceito de material biológico humano, de projeto de pesquisa, do protocolo de desenvolvimento, do sujeito de pesquisa, bem como o Termo de Consentimento Livre e Esclarecido (TCLE).

As diretrizes brasileiras definem a propriedade da amostra biológica humana como do titular do material biológico humano.

A gratuidade da doação de material biológico humano não significa, em absoluto, a

7 In Brazil, the researches involving human beings regulations is protected by the Resolutions of the National Council of Health which, although not having the normative Power of the legal provisions (punishment), set up ethical and regulatory directives which relate the researchers to certain prescriptions, as it is the case of the research approval by determined Ethics Committee.

Revista de Biodireito e Direito dos Animais | e-ISSN: 2525-9695 | Salvador | v. 4 | n. 1 | p. 64 - 83 | Jan/Jun. 
negativa de direitos e possibilidades de normatização ao doador.

Sob a perspectiva dos direitos da personalidade, verifica-se tratar-se de um campo fértil para o desenvolvimento de conflitos éticos. Diante disso, há o reconhecimento e a proteção internacional da dignidade humana, compreendendo-a como direito inalienável.

O Estado deve zelar pela proteção e desenvolvimento desses direitos da personalidade para atingir o bem-estar individual e de toda a coletividade. A garantia do bemestar torna-se uma de suas finalidades, razão pela qual a regulação das pesquisas clínicas em biobancos deve elucidar os deveres destes. Diante disso, determina-se a garantia da privacidade e confidencialidade do titular da amostra biológica humana, com imposição do cumprimento de sua destinação, zelando pelo não desvio de suas finalidades.

A anonimização (confidencialidade) da identidade pessoal e social do doador da amostra biológica humana é imprescindível para garantir o direito de privacidade e confidencialidade do titular da amostra. Neste sentido, disciplina-se o acesso dessas informações somente para diagnóstico futuro de doenças e de doenças familiares ou de testes genéticos em familiares.

Além de seus direitos e garantias fundamentais constitucionalmente assegurados, bem como do regime dos direitos da personalidade, ambos alheios ao objeto do presente trabalho, cabe destacar que o negócio jurídico deve observar seus pressupostos jurídicos de existência e validade.

Logo, além dos requisitos de validade, os deveres anexos oriundos da função integrativa da boa-fé objetiva também se impõem.

\section{O CORPO, O PATRIMÔNIO E O INSTITUTO DA DOAÇÃO NEUTRA}

Consagra-se, desse modo, a necessidade de revisitação do instituto jurídico de direito privado, tendo em vista o reconhecimento do corpo como um bem jurídico integrante do patrimônio da pessoa humana.

A ideia de titularidade sobre o corpo físico já [seja] carregada de ambiguidade, recordam Claire Crignon-De Oliveira e Marie Gaille-Nikodimov que a mera expressão 'é meu corpo' pode ser tomada no sentido de exprimir uma forma de defesa da própria integridade ('é meu corpo, por isso, não me violente', 'não me toque', etc.), quanto pode traduzir a livre disposição sobre o corpo físico, expressando, assim, a ideia de titularidade individual.

No sentido da titularidade individual, é possível afirmar que cabe ao titular do corpo a decisão sobre os limites de cuidados que vai sobre si mesmo dispensar ou não, e 
essa decisão pode abranger desde o non facere até a busca insaciável da perfeição estética e funcional, passando pela autorização de procedimentos médicos menos ou mais invasivos, a prática de esportes violentos ou de alto risco, a forma de sexualidade, o ato de alcoolizar-se, de fazer uso de drogas, de fumar, de fazer regime para emagrecer ou engordar, e tantas outras manifestações que podem ser exercidas, dentre elas a livre disposição do próprio corpo para fins de pesquisas ou de órgãos para fins de transplantes. (MEIRELLES, 2011, p. 225).

Assim, a pessoa humana seria proprietária desse corpo, devendo seu exercício ser regulado por sua autonomia. O primeiro passo para a revisitação de institutos jurídicos diz respeito à alteração da concepção de patrimônio.

[...] patrimônio pode ser compreendido, amplamente, como o complexo de relações jurídicas apreciáveis economicamente (ativas e passivas) de uma determinada pessoa. Ou seja, é a totalidade dos bens dotados de economicidade pertencentes a um titular, sejam corpóreos (casa, automóvel, etc) ou incorpóreos (direitos autorais). (FARIAS; ROSENVALD, 2011, p. 481).

Diante disso, tem-se um conjunto de direitos de valor pecuniário, tendo em vista se tratar de direitos reais e obrigacionais.

[...] Patrimônio, pois, é expressão de largo espectro, englobando tanto os direitos reais, quanto os direitos pessoais (obrigacionais). Refere-se sempre aos bens apreciáveis economicamente, motivo pelo qual não estão compreendidos no patrimônio os direitos de família puros e os direitos da personalidade, ditos extrapatrimoniais. (FARIAS; ROSENVALD, 2011, p. 481).

Entretanto, consta-se que há necessidade de uma releitura do instituto do patrimônio. A ideia de cunho pecuniário deve dar espaço para esfera existencial. Diante disso, emerge a concepção da extrapatrimonialidade, pautada na dignidade humana. Logo, a concepção de um patrimônio atrelado à personalidade do seu titular é decorrência de uma perspectiva constitucional mais humanista, que admite a sua funcionalização em favor da dignidade da pessoa.

[...] premente necessidade de uma nova compreensão da matéria, vislumbrando o patrimônio em perspectiva humanista, afirmando a sua funcionalização à promoção da dignidade do homem. Assim, emerge uma ampliação da ideia de patrimônio para abarcar, não apenas as relações patrimoniais da pessoa, mas, por igual, diferentes outros valores.

Em outras palavras, a tutela jurídica emprestada ao patrimônio não tem outra justificativa, senão a proteção da própria pessoa humana titulariza aquelas relações jurídicas. (FARIAS; ROSENVALD, 2011, p. 484).

O titular do patrimônio terá garantido o exercício de sua autonomia. Por conseguinte, 
revela-se um outro requisito da concepção da autonomia como expressão de liberdade, que consiste no potencial de negociabilidade, isto é, o titular possui ampla liberdade de negociar seus bens através de relações contratuais, observados os limites de ordem pública.

Significa que a doação de material biológico humano para biobancos merece atenção. A doação, que “[...] é o contrato em que uma pessoa, por liberalidade, transfere bens de seu patrimônio para o de outra, que os aceita" (FIÚZA, 2014, p. 648), possui, de início, uma concepção patrimonializada, ou seja, o patrimônio físico, sendo dotado de valor econômico a ser transferido para um terceiro a título gratuito.

A doação consiste no ato em que "[...] o doador transfere do seu patrimônio bens ou vantagens para o donatário, sem a presença de qualquer remuneração. Trata-se de ato de mera liberalidade, sendo um contrato benévolo, unilateral e gratuito" (TARTUCE, 2014, p. 698).

O instituto da doação é tratado, no sistema jurídico brasileiro, ${ }^{8}$ nos artigos $538^{9} \mathrm{e}$ seguintes do Código Civil, como um contrato de transferência de propriedade, havendo duas correntes doutrinárias a respeito de sua natureza jurídica.

Entretanto, “[...] nosso ordenamento jurídico somente reconhece como objeto viável para fins de doação aquele que possua expressão econômica, patrimonial, sendo esse também o entendimento da doutrina" (FARIA; SILVA, 2013, p. 180).

Mas, com os avanços tecnológicos da biotecnologia, o corpo pode ser entendido como integrante do patrimônio, de caráter existencial.

É necessário. Assim, construir um plano de justificação da releitura da doação para dispor a respeito da doação sem caráter patrimonial, visto que "[...] a doação [envolve] o núcleo do direito à intimidade, atingindo, a rigor, a própria esfera da exclusividade" (MARTINS-COSTA; FERNANDES, 2012, p. 242), através da demonstração do instituto e sua aplicabilidade na esfera existencial.

Tal ponto de vista justifica-se em razão do livre desenvolvimento da personalidade, através da autodeterminação e da disposição do próprio corpo pela pessoa humana, tendo em vista o exercício de autonomia privada de forma autônoma e responsável.

Assim, parece haver espaço para a compreensão do instituto da doação como aplicável ao patrimônio genético da pessoa humana. Logo, a disposição de material biológico

A Lei n 10.406/2002 instituiu o Código Civil de 2002.

Art. 538. Considera-se doação o contrato em que uma pessoa, por liberalidade, transfere do seu patrimônio bens ou vantagens para o de outra.

Revista de Biodireito e Direito dos Animais | e-ISSN: 2525-9695 | Salvador | v. 4 | n. 1 | p. 64 - 83 | Jan/Jun. 
humano para biobancos parece poder configurar-se espécie de doação. Nesse viés, perfaz-se doação que, no campo dos negócios jurídicos existenciais, deve ser entendida como um ato de liberalidade, sem caráter econômico e sem o caráter atributivo de propriedade. Vale dizer, esse negócio jurídico dispositivo de material biológico humano para biobancos, pensado pelo prisma da doação, parece configurar-se como doação neutra, apta a gerar responsabilidade quando do desacordo da destinação da amostra biológica humana para o fim específico para o qual foi doado.

Neste sentido, trata-se de um negócio jurídico em que não aufere nenhuma vantagem econômica direta para as partes. Diante disso, o negócio jurídico existencial não pode ser incluído na categoria dos onerosos, nem gratuitos, por não possuir atribuição patrimonial.

Assim, o negócio jurídico neutro não pode ser considerado como negócios translativos, ante a falta de caráter patrimonial, bem como não poderão ser classificados nem como onerosos, nem como gratuitos (GOMES, 2008).

O negócio jurídico existencial sempre será classificado como um negócio jurídico neutro. Entretanto, nem todo negócio jurídico neutro será considerado existencial, visto que existem alguns negócios jurídicos neutros que serão considerados como de natureza extrapatrimonial, que não podem ser considerados existenciais como, por exemplo, a renúncia a herança.

A disposição de material biológico humano em estudo parece enquadrar-se numa perspectiva pertinente a uma doação própria, diversa à existente no ordenamento jurídico pátrio, visto que não há transferência de propriedade.

Desta forma, o titular do material biológico humano não tem uma redução em seu patrimônio genético. Os biobancos donatários, igualmente, não são contemplados com acréscimo patrimonial.

Nesse sentido, “[...] na doação de material biológico humano, não há suscetibilidade à avaliação econômica, não há patrimonialidade, nem circulação interpatrimonial de riqueza. Trata-se, pois, de negócio jurídico existencial” (MARTINS-COSTA; FERNANDES, 2012, p. 238).

"A doação de bens considerados atributos da personalidade ou partes do corpo vivo, sem valor patrimonial, tornou-se faticamente possível com a evolução genética, cumprindo ao direito sua regulamentação" (FARIA; SILVA, 2013, p. 180).

Assim, o Termo de Consentimento Livre e Esclarecido deve ser visto como instrumento de um negócio jurídico existencial, pois reflete verdadeira doação de material Revista de Biodireito e Direito dos Animais | e-ISSN: 2525-9695 | Salvador | v. 4 | n. 1 | p. 64 - 83 | Jan/Jun. 
biológico humano. Confere-se ao titular do material biológico humano a prerrogativa de exercício de liberdade de dispor de material biológico para biobancos, conforme destinação com a qual deve aquiescer.

A doação segue com encargo, o que demonstra parâmetros impostos pelo doador ao donatário, sob pena de responsabilidade. Em todo caso, tratando-se de espectro de direito existencial, a revogação da doação também é cabível. Assim, essa doação é compatível com cláusulas de gravame (inalienabilidade, impenhorabilidade e incomunicabilidade), para proteção do material biológico humano doado para biobancos.

A cláusula da inalienabilidade consiste na proibição dada ao donatário de vender, trocar ou doar a amostra biológica humana constante em biobancos. Nesse sentido, consiste, também em numa cláusula de proteção de conservação da referida amostra, pois o donatário não pode "[...] praticar qualquer ato que implique, ainda que indiretamente, sua perda" (FIÚZA, 2014, p. 658).

A cláusula de impenhorabilidade refere-se à proteção da amostra biológica humana em relação a eventuais credores do donatário.

A cláusula de incomunicabilidade, na esfera patrimonial, consiste na exclusão do “[...] bem doado do patrimônio que o devedor tiver em comum com seu cônjuge ou companheiro" (FIÚZA, 2014, p. 658). Portanto, essa cláusula pode ter sua releitura sob dois aspectos: o primeiro, que a amostra biológica humana não integra o patrimônio do pesquisador, nem dos biobancos, por se tratar de uma doação neutra. O segundo aspecto consiste na demonstração de que a amostra biológica humana constante em biobancos de não será fruto de partilha de bens (do doador ou do donatário).

Ressalte-se, ainda, o aparente cabimento, na doação neutra em estudo, da cláusula de reversão, também conhecida como cláusula de retorno. Conforme art. $547^{10}$ do Código Civil brasileiro, trata-se de “[...] uma condição resolutiva expressa, demonstrando o intento do doador de beneficiar somente o donatário e não os seus sucessores, sendo, portanto, uma cláusula intuito personae que veda a doação sucessiva" (TARTUCE, 2014, p. 708). A cláusula de reversão é marcador de identificação da doação neutra, visto que confere a possibilidade de retorno do material biológico humano para seu titular, ora doador.

Assim, da releitura do instituto de doação, desponta a doação neutra, que possui características especificas, tendo em vista a extrapatrimonialidade do patrimônio genético.

10 Art. 547. O doador pode estipular que os bens doados voltem ao seu patrimônio, se sobreviver ao donatário. Parágrafo único. Não prevalece cláusula de reversão em favor de terceiro. 


\section{DOAÇÃO NEUTRA E A EVENTUAL APLICABILIDADE DO CÓDIGO DE DEFESA DO CONSUMIDOR}

A existência de relação de consumo é o filtro de aplicação do microssistema jurídico do direito do consumidor.

A conclusão pela aplicabilidade do Código de Defesa do Consumidor à relação jurídica formatada pela doação neutra também depende dessa compreensão.

A definição do conceito jurídico de consumidor é objeto de amplo debate doutrinário e jurisprudencial. Pode ser entendido em sentido estrito, ao que prevê o art. $2^{\circ}$ da Lei Federal n. 8.078 (BRASIL, 1990), como toda pessoa física ou jurídica que adquire ou utiliza produto ou serviço como destinatário final. A lei, por meio da adoção do critério da destinação do uso do produto ou serviço, pretende afastar desse grupo os que os adquiriram para empregá-los nos processos diretos de suas atividades profissionais.

A vulnerabilidade, que permanece como conceito jurídico indeterminado, é marca determinante da qualidade de consumidor. Parece ser presumida, quando se trata de pessoa natural, e filtro, para a admissão da pessoa jurídica como destinatária final de produtos e serviços. As nuances possíveis variam desde a vulnerabilidade fática ou econômica do consumidor, que é a mais comum, até a jurídica, técnica ou meramente informacional, aferíveis em concreto. (NOGUEIRA, 2017, p. 192).

Subsistindo dúvida, a interpretação, tanto da formação da relação jurídica quanto das cláusulas contratuais, deve operar-se da maneira mais favorável ao consumidor, em virtude da compreensão teleológica do sistema protetivo e dos preceitos normativos do princípio da boafé objetiva, mormente aqueles que desempenham papel de cânone hermenêutico-integrativo. (NOGUEIRA, 2017, p. 194).

O consumidor não é somente e necessariamente aquele que contrata com o fornecedor e que usufrui de seus serviços ou produtos. O Código de Defesa do Consumidor (BRASIL, 1990) impõe, por força do parágrafo único do art. $2^{\circ}$ e dos artigos 17 e 29, seja equiparada a consumidores a coletividade de pessoas, ainda que indetermináveis, que intervenha nas relações de consumo; todas as vítimas do fato do produto ou serviço; além de todos aqueles que, determináveis ou não, sejam expostos a práticas comerciais.

O fornecedor, sobre cujo conceito repousam poucas ambiguidades, é elemento subjetivo, igualmente imprescindível para que se formate a relação de consumo, 
diferenciando-a da relação jurídica de direito civil comum. Fornecedor é toda pessoa física ou jurídica, pública ou privada, nacional ou estrangeira, bem como os entes despersonalizados, que desenvolvem atividade de produção, montagem, criação, construção, transformação, importação, exportação, distribuição ou comercialização de produtos ou prestação de serviços. A visão é ampla, condizente com o propósito protetivo desse microssistema. (NOGUEIRA, 2017, p. 194).

Fornecedor é gênero que define aquele que desenvolve atividade de produção ou circulação de bens ou de serviços, com profissionalismo, leia-se, com habitualidade, tendo-a como atividade-fim. (BRASIL, 1990)

Também elementos essenciais à relação de consumo, ao lado dos já explicitados fatores subjetivos e teleológicos (a destinação dada pelo consumidor ao objeto do contrato de consumo), apresentam-se os ditos elementos objetivos, que são as prestações almejadas pelo consumidor, resultantes da disponibilidade de riquezas e conveniências na sociedade de consumo. São produtos ou serviços. Produto é qualquer bem, móvel ou imóvel, material ou imaterial. (BRASIL, 1990) Serviço é qualquer atividade fornecida no mercado de consumo, mediante remuneração (mesmo que essa seja expressão de lucratividade indireta), inclusive as de natureza bancária, financeira, de crédito e securitária, salvo as decorrentes das relações de caráter trabalhista. (NOGUEIRA, 2017, p. 194).

Nesses moldes, presentes todos os alegóricos subjetivos, objetivos e teleológicos previstos pelo Código de Defesa do Consumidor (BRASIL, 1990), desenha-se a relação de consumo.

Assim, ainda que diante da doação neutra de material biológico humano, nos casos de biobancos mantidos por fornecedores de serviços onerosos de pesquisa ou terapêutica, cabe considerar o doador como verdadeiro consumidor. Afinal, há remuneração pelo serviço prestado e o doador encontra-se sujeito a práticas comerciais correlatas. Logo, as atividades do fornecedor de serviços ligados a biobancos regulam-se, também, pelo Código de Defesa do Consumidor (BRASIL, 1990), de modo que o doador recebe a proteção do regime jurídico consumerista, podendo valer-se dele para buscar desde a coibição de prática abusiva até a facilitação dos meios de defesa, pela via da inversão do ônus da prova.

Dessa maneira, a relação entre doador e donatário de material biológico humano especializa a exigência de atenção e cuidados do segundo para com o primeiro, preservandolhe a autonomia e, em última análise, a dignidade. O princípio da boa-fé objetiva introduz deveres laterais ou anexos, independentemente de sua previsão pelas partes contratantes. Esse Revista de Biodireito e Direito dos Animais | e-ISSN: 2525-9695 | Salvador | v. 4 | n. 1 | p. 64 - 83 | Jan/Jun. 
mesmo princípio, expressamente consagrado no Código de Defesa do Consumidor (BRASIL, 1990), transfere toda a sua carga deontológica ao microssistema do direito do consumidor, reafirmando a sua ênfase e prevalência sobre a autonomia do contratante, especialmente porque esse regime jurídico comporta orientações de ordem pública, com explícito fito protetivo, com a finalidade de promoção do equilíbrio de uma relação que, comumente, pode acabar firmando-se em prejuízo da justiça contratual e da função social.

Dos deveres anexos ou laterais, impassíveis de enumeração exaustiva, tem destaque, na relação médico/paciente, o dever de informação, desdobrando-se no dever de transparência ou esclarecimento. Ademais, há que se falar nos deveres de proteção e cuidado. Informação vincula-se à decisão quanto à qualidade e destinação dos materiais integrantes das bases de biobancos. Proteção e cuidado são indissociáveis do dever de sigilo, pois versam sobre a preservação da intimidade. (NOGUEIRA, 2017, p. 192). Despontam-se sempre que a informação e melhor interesse dos vulneráveis envolvidos sejam relevantes para a anonimização (confidencialidade de dados) do doador do material biológico humano.

A respeito do dever de esclarecimento, Menezes Cordeiro (2007) explica:

O campo mais produtivo no domínio do dever de esclarecimento é o dos contratos de prestação de serviços médicos, utilizáveis como exemplares. O âmbito do dever médico de esclarecimento estende-se aos efeitos típicos das terapêuticas prescritas e não todos os seus efeitos possíveis que estas possam acarretar; varia, ainda, em profundidade, consoante a inteligência e os conhecimentos do paciente e as necessidades do caso. (CORDEIRO, 2007, p. 605-606).

O dever de informar volta-se à garantia de esclarecimento do doador quanto às destinações e riscos pertinentes à manutenção e articulação dos biobancos para a prestação de serviços de saúde, de modo que cabe detalhar as vantagens, probabilidades conhecidas, riscos, custos e outras intercorrências.

Quando da abordagem do doador, os perfis atuais dos atores relacionais carregam a marca indelével de uma autonomia marcada por elementos de heteronomia e que se edifica, sobretudo, dialogicamente. (NOGUEIRA, 2017, p. 193). Isso fica evidente quando não adianta ao donatário expor tal conteúdo material sem que seja em linguagem clara e acessível.

Vale dizer, portanto, que o doador de material biológico humano para biobancos é parte de uma relação de consumo, recebendo, assim, a regência própria do Código de Defesa do Consumidor. 


\section{CONSIDERAÇÕES FINAIS}

Se o corpo deve ser entendido como elemento para a formação de identidade pessoal e social, sendo determinante da pessoalidade, a concepção contemporânea de corpo como integrante do patrimônio pessoal permite não apenas a individualização da pessoa, mas também a sua suscetibilidade ao autogoverno conferido a cada um.

Logo, o direito ao corpo emerge como direito compreendido no exercício da autonomia privada, representando a concepção da dignidade como autonomia, através do exercício de uma moralidade racional. Trata-se de direito da personalidade, dotado de tutela jurídico-política do Estado Democrático de Direito em prol da efetividade do livre desenvolvimento da personalidade.

Os avanços da Biotecnologia colocam em voga a disposição de material biológico humano para a instituição de biobancos e seu regime jurídico. Cabe, aqui, a indagação acerca da natureza jurídica dessa relação, bem como sobre o regime jurídico incidente.

Essa liberalidade de disposição de material biológico humano para a instituição de biobancos implementa-se pela manifestação de vontade do titular da amostra, apta a lastrear negócio jurídico existencial.

Com base no reconhecimento do corpo como integrante de patrimônio genético, cabe cogitar da categorização desse negócio jurídico existencial como espécie de doação neutra. Com caráter existencial e extrapatrimonial, é dotada de características próprias. Sem caráter econômico, define-se como ato de liberalidade esboçado pelo consentimento exarado no Termo de Consentimento Livre e Esclarecido (TCLE), sem implicar transferência de patrimônio entre as partes.

O doador, apesar da gratuidade do negócio jurídico existencial neutro e da inexistência de consumo direto de serviços de saúde que se valem dos biobancos mantidos, pode ser equiparado a consumidor, na medida em que for reconhecida sua vulnerabilidade, bem como a remuneração, ainda que indireta, dos fornecedores de serviços médicos mantenedores de bancos de dados biológicos, seja para finalidades de investigação científica, seja para destinação terapêutica de terceiros.

Logo, nessas hipóteses, mesmo a doação neutra deverá pautar-se pelos parâmetros de regência das relações consumeristas, com ênfase nos deveres laterais decorrentes da boa-fé objetiva. Sobrelevam-se, dessa forma, como requisitos de licitude do negócio jurídico existencial, a observância dos deveres de informação, cuidado, proteção do doador. O Termo Revista de Biodireito e Direito dos Animais | e-ISSN: 2525-9695 | Salvador | v. 4 | n. 1 | p. 64 - 83 | Jan/Jun. 
de Consentimento Livre e Esclarecido (TCLE), enquanto instrumento da doação neutra, há de prezar pelo resguardo do direito de liberdade do titular da amostra biológica humana.

Por se tratar de uma doação neutra sem atribuição econômica ou patrimonial, cabe revogabilidade imotivada, assim como cláusulas de inalienabilidade, impenhorabilidade e incomunicabilidade da amostra.

Logo, nas circunstâncias destacadas, há de se aplicar o Código de Defesa do Consumidor (BRASIL, 1990) nos negócios jurídicos existenciais advindos da doação neutra, para a proteção do doador vulnerável do material biológico humano em relação ao donatário, de modo a resguardar, assim, o exercício de autodeterminação e de autonomia, bem como a facilitar o atendimento de suas necessidades, o respeito à sua saúde e segurança, além da proteção de seus demais interesses envolvidos.

\section{REFERÊNCIAS}

ARRIBAS, Maria Concepción Martín; DÍAZ, Javier Arias. Biobancos y utilización de muestras de origem humano em investigación quirúrgica. Marco Normativo Actual. Revista Cirurgia Española - CIR ESP, Madrid, v. 89, n. 4, p. 207-212, 2011.

ASHTON-PROLLA, Patrícia et al. Biobanco do Hospital de Clínicas de Porto Alegre: aspectos técnicos, éticos, jurídicos e sociais. Revista HCPA, Porto Alegre, v. 29, n.1, p. 74-79, 2009.

BAKER, Monya. Biorepositories: building better biobanks. Nature - Technology Features, New York, n. 486, p. 141-146, 2012.

BRASIL. Constituição (1988). Constituição da República Federativa do Brasil, de 05 de outubro de 1988. Diário Oficial da União, Brasília, 05 out. 1988. Disponível em: <http://ww w.planalto.gov.br/ccivil_03/Constituicao/Constituicao.htm>. Acesso em: 10 mar. 2018.

BRASIL. Lei Federal n. 8.078, de 11 setembro 1990. Dispõe sobre a proteção do consumidor e dá outras providências. Diário Oficial da União, Brasília, 12 set. 1990. Disponível em: < http://www.planalto.gov.br/ccivil_03/leis/18078.htm>. Acesso em: 29 mar. 2018.

BRASIL. Ministério da Saúde. Portaria no 2.201, de 14 de setembro de 2011. Estabelece as Diretrizes Nacionais para Biorrepositório e Biobanco de Material Biológico Humano com Finalidade de Pesquisa. Diário Oficial União, Brasília, 15 set. 2011. Disponível em: <http://bvs ms.saude.gov.br/bvs/saudelegis/2011/prt2201_14_09_2011.html>. Acesso em: 10 out. 2015.

CONSELHO NACIONAL DE SAÚDE. Resolução CNS nº 441, de 12 de maio de 2011. Aprovar as seguintes diretrizes para análise ética de projetos de pesquisas que envolvam armazenamento de material biológico humano ou uso de material armazenado em pesquisas anteriores. Diário Oficial União, Brasília, 18 jul. 2011. Disponível em: <http://bvsms.saude. 
gov.br/bvs/saudelegis/cns/2011/res0441_12_05_2011.html>. Acesso em: 20 mar.2018.

CORDEIRO, Antônio Manuel da Rocha e Menezes. Da boa-fé no direito civil. Coimbra: Almedina, 2007.

DUCATO, Rossana; PERRA, Silvia; ZUDDAS, Carla. The legal fate of biobanks between privacy, IPRs and crisis of a firm. A prelimary study on the case of "bio-bankruptcy". Revista de Derecho y Genoma Humano - Law and the Human Genome Review, Bilbao, n. 41, p. 89102, 2014.

FARIA, Alexandra Clara Ferreira; SILVA, Flávia Helena Millard Rosa da. Doação de material genético: um estudo sobre sua permissibilidade jurídica. In: MOUREIRA, Diogo Luna; ALMEIDA, Renata Barbosa de; SÁ, Maria de Fátima Freire de (Coord.). Direito privado: revisitações. Belo Horizonte: Arraes Editores, 2013. p. 171-190.

FARIAS, Cristiano Chaves de; ROSENVALD, Nelson. Direito civil: teoria geral. 9. ed. Rio de Janeiro: Lúmen Júris, 2011.

FIÚZA, César. Direito civil: curso completo. 17. ed. Belo Horizonte: Del Rey, 2014.

GOMES, Orlando. Introdução ao direito civil. 19. ed. rev., atual. e aum., de acordo com o Código Civil de 2002, por Edvaldo Brito e Reginalda Paranhos de Brito. Rio de Janeiro: Forense, 2008.

GOZZO, Débora; LIGIERA, Wilson Ricardo. O consentimento informado como direito de personalidade. In: GOZZO, Débora; LIGIERA, Wilson Ricardo (Org.). Bioética e direitos fundamentais. São Paulo: Saraiva, 2012, p. 93-113.

MARTINS-COSTA, Judith; FERNANDES, Márcia Santana. Os biobancos e a doação de material biológico humano: um ensaio de qualificação jurídica. In: GOZZO, Débora; LIGIERA, Wilson Ricardo (Org.). Bioética e direitos fundamentais. São Paulo: Saraiva, 2012. p. 223-259.

MEIRELLES, Jussara Maria Leal de. Proteção jurídica do embrião. In: TEIXEIRA, Ana Carolina Brochado; RIBEIRO, Gustavo Pereira Leite (Coord.). Manual de teoria geral do direito civil. Belo Horizonte: Del Rey, 2011. p. 215-228.

MOTA, Joaquim Antônio César. Aspectos éticos envolvidos na incorporação de novas tecnologias em Medicina. O Mundo da Saúde, São Paulo, ano 21, v. 21, n. 2, p. 113-118, mar./abr. 1997.

NOGUEIRA, Roberto Henrique Pôrto. Prescrição off label de medicamentos: ilicitude e responsabilidade civil do médico. Belo Horizonte: Editora PUC Minas, 2017.

RODOTÀ, Stefano. La vida y las reglas: entre el derecho y el no derecho. Madrid: Editorial Trotta, 2010.

ROMEO CASABONA, Carlos María; SIMON, Jurgen W. Biobanking: a chance for scientific Revista de Biodireito e Direito dos Animais | e-ISSN: 2525-9695 | Salvador | v. 4 | n. 1 | p. 64 - 83 | Jan/Jun. 
research and a challenge for intelectual property rights and privacy. In: ROMEO

CASABONA, Carlos Maria et al. Latinbanks: study on the legal and social implications of creating banks of biological material for biomedical research. Espanha: Bruylant Bruxelles, 2011. p. 05-15.

SÁ, Maria de Fátima Freire de. Legal and social implications of creating banks of biological material in Brazil. In: ROMEO CASABONA, Carlos Maria et al. Latinbanks: study on the legal and social implications of creating banks of biological material for biomedical research. Espanha: Bruylant Bruxelles, 2011. p. 29-56.

TARTUCE, Flávio. Manual de direito civil. Rio de Janeiro: Método, 2014. 